\title{
STUDI TRANSFORMASI ZEOLIT ALAM ASAL SUKABUMI DENGAN MENGGUNAKAN AIR ZAMZAM SEBAGAI SUMBER AKUADES
}

\author{
RIKI JUNIANSYAH $^{1}$, DEDE SUHENDAR ${ }^{1 *}$, DAN EKo PRABOWO HADISANTOSO ${ }^{1}$ \\ ${ }^{1}$ Jurusan Kimia, Fakultas Sains dan Teknologi, UIN Sunan Gunung Djati Bandung, \\ Jl. A.H. Nasution No. 105, Bandung \\ *Email korespondensi: dede.suhendar@uinsgd.ac.id
}

\begin{tabular}{|c|c|}
\hline Informasi Artikel & Abstrak/Abstract \\
\hline $\begin{array}{l}\text { Riwayat Naskah : } \\
\text { Diterima pada } 29 \\
\text { Mei } 2017 \\
\text { Diterima setelah } \\
\text { direvisi pada } 29 \text { Juni } \\
2017 \\
\text { Diterbitkan pada } 30 \\
\text { Juni } 2017 \\
\text { Kata Kunci: zeolit } \\
\text { alam; transformasi; } \\
\text { air zamzam; } \\
\text { hidrotermal; zeolit } \\
\text { faujasit; zeolit } \\
\text { analsim. }\end{array}$ & $\begin{array}{l}\text { Zeolit alam asal Sukabumi memiliki tiga komposisi mineral, yaitu kuarsa, mordenit, dan } \\
\text { klinoptilolit. Setiap jenis zeolit memiliki kegunaan yang berbeda-beda, untuk meningkatkan } \\
\text { nilai lebih dari zeolit alam, maka dari itu perlu adanya pengembangan zeolit alam mengingat } \\
\text { zeolit alam asal Sukabumi lebih cenderung kepada jenis zeolit mordenit. Dari permasalahan } \\
\text { tersebut perlu adanya penelitian tentang studi transformasi zeolit alam asal Sukabumi untuk } \\
\text { mengetahui jenis zeolit baru yang akan dihasilkan dari transformasi tersebut dan hasil } \\
\text { karakterisasinya. Tansformasi zeolit alam dilakukan dalam tiga variasi komposisi } \\
\text { perbandingan mol yaitu } 1 \text { zeolit : } 4 \mathrm{NaOH:} 40 \text { air zamzam, } 1 \text { zeolit : } 2 \mathrm{NaOH:} 40 \text { air zamzam, } \\
1 \text { zeolit : } 0 \mathrm{NaOH} \text { : } 40 \text { air zamzam. Transformasi ini dilakukan dengan metode hidrotermal } \\
\text { pada suhu } 150^{\circ} \mathrm{C} \text { selama } 12 \text { jam. Hasil transformasi perbandingan variasi mol tersebut } \\
\text { menghasilkan zeolit faujasit, analsim, mordenit, dan mineral kuarsa. Karakterisasi dengan } \\
\text { difraksi sinar-X yang mengkonfirmasi terbentuknya zeolit faujasit, analsim, mordenit, dan } \\
\text { mineral kuarsa. }\end{array}$ \\
\hline $\begin{array}{l}\text { Keywords: natural } \\
\text { zeolite; } \\
\text { transformation; } \\
\text { zamzam water; } \\
\text { hydrothermal; zeolite } \\
\text { faujasite; zeolite } \\
\text { analcime. }\end{array}$ & $\begin{array}{l}\text { Natural zeolite from Sukabumi has three mineral composition, namely quartz, mordenite, and } \\
\text { clinoptilolite. Each type of zeolite has different uses, to increase the value of natural zeolites, } \\
\text { then there is need for the development of natural zeolite given natural zeolite from Sukabumi } \\
\text { more inclined to this type of zeolite mordenite. Of these problems need research on the study } \\
\text { of transformation Natural zeolites from Sukabumi to know what types of new zeolites to be } \\
\text { derived from such a transformation. Transformation of natural zeolite done in three } \\
\text { variations: } 1 \text { mol ratio of zeolite: } 4 \mathrm{NaOH:} 40 \mathrm{Zamzam} \text { water, } 1 \text { zeolites: } 2 \mathrm{NaOH}: 40 \\
\text { Zamzam water, } 1 \text { zeolite: } 0 \mathrm{NaOH}: 40 \mathrm{Zamzam} \text { water. This transformation is performed by } \\
\text { hydrothermal method at } 150{ }^{\circ} \mathrm{C} \text { for } 12 \text { hours. The result of the transformation ratio of the mole } \\
\text { variations produce zeolite faujasite, analcime, mordenite, and quartz mineral. } \\
\text { Characterization by X-ray diffraction to confirm the formation of zeolite faujasite, analcime, } \\
\text { mordenite, and quartz mineral. }\end{array}$ \\
\hline
\end{tabular}

\section{PENDAHULUAN}

Zeolit merupakan kelompok mineral yang dalam pengertian/penamaan salah satu jenis bahan galian non logam atau bahan galian mineral industri dari 50 jenis yang ada. Sampai saat ini lebih dari 50 mineral pembentuk zeolit alam sudah diketahui, tetapi hanya sembilan diantaranya yang sering ditemukan, yaitu klinoptilolit, mordenit, analsim, khabasit, erionit, ferierit, heulandit, laumonit, dan filipsit.

Dari hasil penelitian yang pernah dilakukan, jenis mineral zeolit yang terdapat di Indonesia adalah modernit dan klipnoptilolit. Zeolit alam ini terbentuk dari reaksi antara batuan tufa asam berbutir halus dan bersifat riolitik dengan air pori atau air meteorik (air hujan). Mineral ini merupakan kelompok aluminosilikat terhidrasi dengan unsur utama terdiri dari kation, alkali dan alkali tanah, mempunyai pori-pori yang dapat diisi oleh molekul air. Kandungan air yang terperangkap dalam rongga zeolit biasanya berkisar $10-50 \%$. Bila terhidrasi kation-kation yang berada dalam rongga tersebut akan terselubungi molekul air, molekul air ini sifatnya labil atau mudah terlepas [1].

Pemanfaatan zeolit untuk digunakan dalam berbagai industri dan pertanian akhir-akhir ini berkembang cukup pesat. Banyak pengusaha, baik swasta, nasional, KUD maupun perorangan membuka usaha penambangan di berbagai daerah. Ada yang masih tetap berjalan hingga saat ini, namun ada juga yang sementara berhenti. Memperhatikan pentingnya pemanfaatan zeolit dalam berbagai industri dan pertanian serta upaya mengangkat perekonomian masyarakat dimasa krisis ekonomi yang belum juga pulih ini, diperlukan adanya dorongan untuk 
mendayagunakan potensi zeolit secara lebih optimal. Dalam pemanfaatannya, zeolit telah mengalami pengembangan sehingga dapat digunakan untuk beberapa keperluan dalam industri dan pertanian, bahkan untuk lingkungan. Selain itu, zeolit dapat menghilangkan bau karena zeolit dapat menyerap molekul-molekul gas seperti $\mathrm{CO}, \mathrm{CO}_{2}, \mathrm{H}_{2} \mathrm{~S}$, dan lainnya. Zeolit digunakan sebagai bahan galian non-logam atau mineral industri multiguna karena memiliki sifatsifat fisika dan kimia yang unik yaitu sebagai penyerap, penukar ion, penyaring molekul, dan sebagai katalisator [2].

Indonesia merupakan daerah vulkanik yang kaya akan bahan galian industri terutama kelompok mineral alumino-tekto-silikat seperti zeolit. Secara geologi sumber daya mineral tersebut tersebar hampir di setiap pulau di Indonesia mulai dari Jawa, Sumatera, Kalimantan, hingga Sulawesi. Sehingga perkiraan jumlah cadangan zeolit alam Indonesia sangatlah melimpah. Di Jawa Barat bagian selatan sangat banyak potensi sumberdaya bahan galian mineral yang sampai saat ini penanganan dan pemanfaatannya belum dikelola secara maksimal. Salah satu bahan galian tersebut adalah zeolit, hampir di setiap kabupaten di Jawa Barat bagian selatan terdapat bahan galian mineral zeolit di antaranya, Sukabumi, Tasikmalaya, dan Ciamis [3].

Zeolit alam asal Sukabumi terdiri atas tiga komposisi mineral, yaitu kuarsa, mordenit dan klinoptilolit. Berdasarkan hasil karakterisasi XRD, zeolit ini lebih cenderung kepada jenis zeolit mordenit. Seiring dengan perkembangan zaman dan teknologi, penggunaan zeolit di berbagai sektor pula semakin pesat dan zeolit menjadi salah satu kebutuhan pokok dalam sektor tersebut. Setiap jenis zeolit memiliki kegunaan yang berbeda-beda, untuk meningkatkan nilai lebih dari zeolit alam, maka dari itu perlu adanya pengembangan zeolit alam mengingat zeolit alam asal Sukabumi lebih cenderung kepada jenis zeolit mordenit. Dari permasalahan tersebut perlu adanya percobaan tentang studi transformasi zeolit alam asal Sukabumi untuk mengetahui jenis zeolit yang dihasilkan dari transformasi tersebut. Pada umumnya zeolit disintesis dari fase amorf dirubah menjadi suatu jenis zeolit dengan proses transformasi malalui media cair. Zeolit memiliki sifat metastabil sehingga urutan perubahan yang sering di amati yaitu berawal dari fase amorf menjadi zeolit tidak stabil kemudian menjadi zeolit stabil. Transformasi zeolit yang paling stabil dapat dilakukan melalui proses secara termodinamika, akan tetapi pada tahap akhir proses ini dipengaruhi oleh interaksi proses nukleasi, pertumbuhan dan transformasi fase kinetik. Hasil perhitungan teoritis dan pengukuran secara kalorimetrik telah menghasilkan hipotesis bahwa stabilitas zeolit menurun seiring dengan meningkatnya porositas yaitu, menunjukan kepadatan kerangka zeolit menurun. Pada kenyataannya, beberapa kelompok penelitian telah menunjukkan potensi yang tinggi terhadap metode alternatif untuk pembentukan zeolit, yaitu, konversi hidrotermal dari satu jenis zeolit ke jenis zeolit lainnya (konversi interzeolite) [4].

Zeolit buatan yang dihasilkan dari sintesis/transformasi/modifikasi terdiri atas gel alumino-silikat dengan mencontoh proses hidrotermal pada salah satu proses mula jadi zeolit alam. Jenis gel tersebut dibuat dari larutan natrium aluminat, natrium silikat, dan natrium hidroksida. Ada tiga jenis bahan kimia di pasaran yang mirip kegunaannya dengan zeolit alam, yaitu silika gel karbon aktif, dan zeolit buatan. Berdasarkan penelitian sebelumnya, kemampuan karbon aktif dan silika gel sebagai bahan penyerap tidak melebihi zeolit alam. Sedangkan zeolit buatan lebih murni dan mempunyai kemampuan lebih luas` dibandingkan dengan zeolit alam, terutama sebagai bahan katalis [1]. Pada penelitian ini digunakan air zamzam karena air zamzam merupakan air yang memiliki $\mathrm{pH}$ basa dan terdapat ion-ion terlarut didalamnya. Digunakannya air zamzam tersebut untuk mengetahui seberapa besar pengaruh air zamzam pada transformasi zeolit alam asal Sukabumi.

\section{EKSPERIMEN}

Penelitian mengenai transformasi zeolit alam ini menggunakan zeolit alam asal Sukabumi yang dilakukan dua tahap, yaitu: transformasi dengan berbagai variasi perbadingan mol dengan metode hidrotermal. Zeolit hasil transformasi kemudian dikarakterisasi dengan menggunakan $X$ Ray Difraction (XRD).

\section{Material}

Bahan yang digunakan pada penelitian ini terdiri atas: zeolit alam asal Sukabumi, $\mathrm{NaOH}$ (PUDAK)., air zamzam dan akuades.

\section{Instrumentasi}

Instrumen yang digunakan dalam penelitian ini adalah X-Ray Difraction (XRD) Philips Pt414241.

\section{Prosedur}

Pada penelitian ini dilakukan dua tahap, yaitu tahap pertama transformasi zeolit alam asal 
Sukabumi dan tahap kedua yaitu karakterisasi zeolit hasil transformasi. Proses transformasi zeolit alam asal Sukabumi dilakukan berdasarkan perbandingan mol zeolit: $\mathrm{NaOH}$ air zamzam pada rentang 1:4:40, 1:2:40, dan 1:0:40, dengan pemanasan pada $150^{\circ} \mathrm{C}$ selama $12 \mathrm{jam}$. Pada tahap kedua dilakukan karakterisasi terhadap hasil zeolit yang ditransformasi yaitu dengan menggunakan $X$-Ray Difraction (XRD).

\section{Transformasi Zeolit}

Transformasi zeolit alam dilakukan dengan cara 3 variasi Perbandingan mol yaitu zeolit:NaOH:air zamzam yang gunakan pada rentang 1:4:40, 1:2:40, dan 1:0:40. Ketiga campuran dimasukkan ke dalam otoklaf, kemudian dipanaskan pada suhu $150{ }^{\circ} \mathrm{C}$ selama 12 jam. Selanjutnya dicuci dengan akuades dan di keringkan pada suhu $100^{\circ} \mathrm{C}$ selama 3 jam.

\section{Analisis Karakterisasi Zeolit Hasil Transformasi}

Karakterisasi dilakukan untuk mengetahui struktur kristalin dari zeolit hasil transformasi yang diuji dengan menggunakan X-Ray Difraction (XRD).

\section{HASIL DAN PEMBAHASAN}

\section{Transformasi Zeolit}

Pada penelitian ini dilakukan transformasi terhadap zeolit alam asal Sukabumi yang memiliki komposisi mineral zeolit mordenit, zeolit klinoptilolit dan mineral kuarsa. Meskipun terdapat tiga komposisi mineral zeolit asal sukabumi lebih cenderung kepada zeolit mordenit. Zeolit alam ini cukup melimpah di daerah Sukabumi, maka dari itu perlu dilakukan studi transformasi untuk mengetahui jenis zeolit baru yang dihasilkan dari transformasi dan karakterisasi yang dilakukan. Zeolit alam biasasnya mengandung banyak impiuritas (pengotor), poripori yang tidak seragam dan kekuatan asam yang sulit dikontrol.

Zeolit alam mempunyai karakteristik yang berbeda dengan zeolit hasil transformasi. Pembentukan zeolit alam dipengaruhi oleh kondisi geografis geoligi alam, sedangkan zeolit hasil transformasi dipengaruhi teknis transformasi, kondisi proses pembuatan dan komposisi bahan [5]. Zeolit alam asal Sukabumi terdiri atas tiga komposisi mineral yaitu zeolit mordenit, zeolit klinoptilolit dan juga minetal kuarsa, dapat dilihat pada Gambar 1. Hasil pengujian XRD sampel zeolit alam asal Sukabumi. Namun zeolit ini lebih cenderung kepada jenis zeolit mordenit. Pada dasarnya transformasi merupakan proses perubahan jenis zeolit satu kepada jenis zeolit yang lainnya dimana perubahan ini terjadi karena teknis transformasi dan adanya cincin yang sama dalam struktur kerangka zeolit sampel dan zeolit yang dihasilkan dari transformasi tersebut.

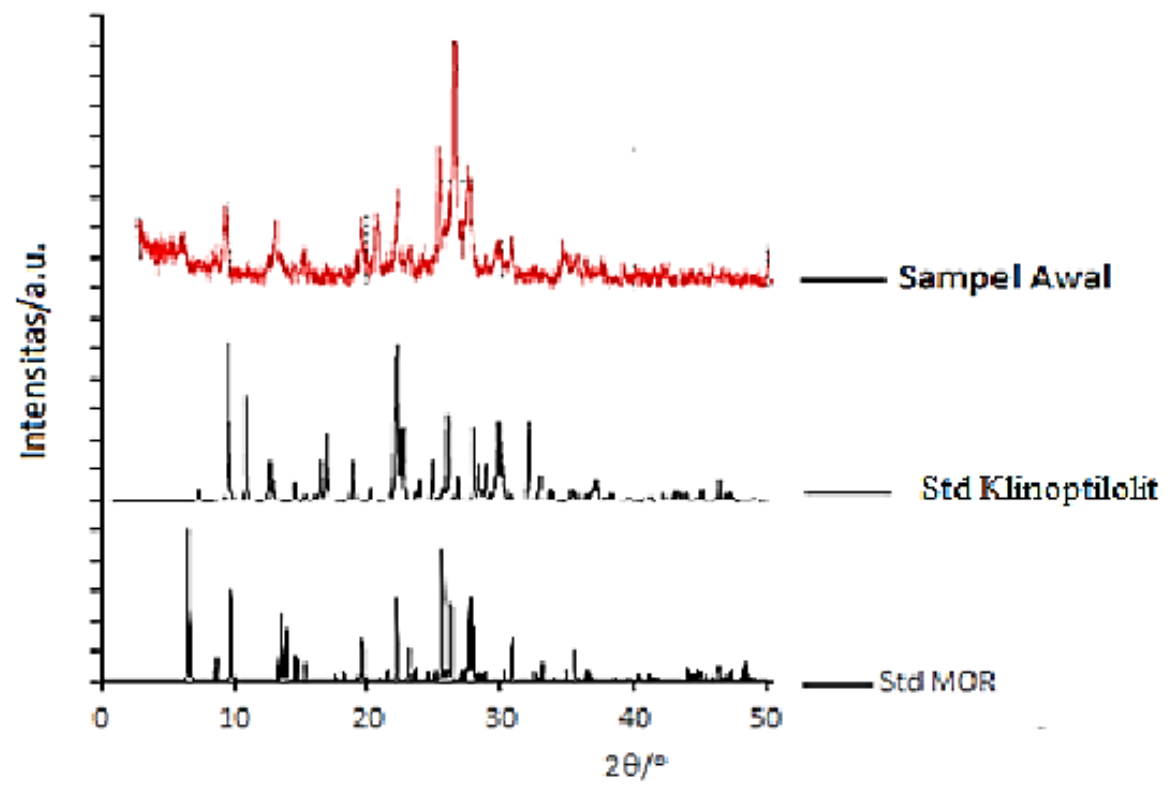

Gambar 1. Difraktogram sampel awal zeolit alam asal sukabumi, standar zeolit klinoptilolit, standar zeolit mordenit.

Transformasi zeolit alam yang dilakukan pada penelitian ini mengunakan bahan-bahan yang terdiri atas: zeolit alam asal Sukabumi sebagai sampel awal, $\mathrm{NaOH}$ (p.a) 50\%, akuades dan air zamzam. Metode yang digunakan pada penelitian ini adalah dengan metode hidrotermal. Dalam metode ini memanfaatkan panas air, suhu, dan tekanan. Pada proses pembentukan zeolit 
dipengaruhi oleh $\mathrm{NaOH}$, air zamzam dan suhu. $\mathrm{NaOH}$ dalam air akan terionisasi menjadi ion $\mathrm{Na}^{+}$ dan $\mathrm{OH}^{-}$dimana $\mathrm{Na}^{+}$berperan sebagai sumber mineral dan ion $\mathrm{OH}_{-}$ini berperan proses dealuminasi dan pemutus rantai silika (mineraliser) menjadi ion-ion/ rangkaian molekul yang lebih kecil. Dengan penambahan $\mathrm{NaOH}$ ini menyebabkan kerangka dari zeolit mordenit terurai karena ada pemutusan rantai Si dan proses dealuminasi membentuk unit-unit bangunan sekunder. Air zamzam yang dignakan berperan sebagai pelarut serta templat anorganik karena air zamzam memiliki kandungan ion ion lebih tinggi jika dibandingkan dengan akuades, sehingga air zamzam dapat berperan sebagai templat anorganik atau agen pengarah struktur dari zeolit. Kerangka zeolit mordenit yang terurai bersatu kembali membentuk kerangka zeolit yang baru dengan bantuan ion-ion yang terkandung dalam air zamzam. Pada proses hidrotermal dilakukan dalam keadaan tertutup. Terjadi fase kesetimbangan, sehingga terjadi reaksi pemutusan ikatan Si-O/Al-O setelah pemanasan dengan terbentuk ikatan $\mathrm{Si}-\mathrm{O}-\mathrm{Al}$ [8].

Pada dasarnya, proses sintesis hidrotermal zeolit terdiri dari dua tahap: pembentukan awal dari gel aluminosilikat terhidrasi dan proses kristalisasi berikut gel. Bahkan, proses kristalisasi dari gel aluminosilikat terhidrasi sangat rumit. Sejauh ini tidak ada kesimpulan yang menyatakan telah tercapainya proses kristalisasi yang rumit ini. Namun, terlepas dari mekanisme liquid atau transformasi fase padat yang diusulkan sebelumnya, umumnya diterima bahwa proses kristalisasi terdiri dari empat langkah:

1) Kondensasi poli silikat dan anion aluminat;

2) Nukleasi zeolit;

3) Pertumbuhan inti; dan

4) Pertumbuhan kristal zeolit yang kadangkadang menyebabkan nukleasi sekunder [6].

Hal ini masih sangat sulit untuk mencapai pemahaman yang mendalam tentang mekanisme pembentukan dan proses kristalisasi rinci zeolit karena:

a) Proses kristalisasi seluruh melibatkan reaksi kimia yang sangat rumit;

b) Nukleasi dan pertumbuhan kristal dilakukan dalam kondisi yang heterogen; dan

c) Seluruh proses terus berubah dengan waktu [6].

Penelitian ini dilakukan tiga variasi, adapun variasi perbandingan mol nya adalah 1 Zeolit : 4 $\mathrm{NaOH}$ : 40 Air zamzam (Percobaan A), 1 Zeolit : $2 \mathrm{NaOH}: 40$ Air zamzam (Percobaan B), 1 Zeolit : $0 \mathrm{NaOH}$ : 40 Air zamzam (Percobaan C).

\section{Transformasi Percobaan A}

Transformasi pada perbandingan ini berdasarkan karakterisasi difraksi sinar-X menghasilkan zeolit faujasit dan mineral kuarsa. Percobaan ini dilakukan dengan metode hidrotermal pada suhu $15^{\circ} \mathrm{C}$. Pemanasan suhu $150^{\circ} \mathrm{C}$ pada transformasi ini bertujuan untuk merubah kerangka zeolit mordenit dan membentuk jenis zeolit baru, suhu yang digunakan cukup tinggi dikarenakan kerangka zeolit mordenit cukup stabil dengan kerapatan sebesar $17,2 \mathrm{~T} / 1000 \AA^{3}$. Pada metode hidrotermal dimana dalam metode ini memanfaatkan panas air, dan tekanan uap air (suhu dan tekanan). Ketiga komponen (air, suhu, dan tekanan) ini saling berkaitan satu sama lain dalam proses hidrotermal ini, air zamzam bertindak sebagai pelarut $\mathrm{NaOH}$ menjadi ion-ion $\mathrm{Na}^{+}$dan $\mathrm{OH}^{-}$sekaligus sebagai medium reaksi penghantaran ion-ion, semakin tinggi suhu maka semakin tinggi pula tekan uap air sehingga terjadi pemotongan kerangka dari zeolit alam yang kompleks menjadi unit bangunan sekunder.

Mekanisme reaksi dari pembentukan zeolit sangat rumit, sampai saat ini belum ada yang mengetahui mekanisme reaksi secara jelasnya. Namun proses pembentukan kristal zeolit secara umum terjadi melalui beberapa tahap. Proses pembentukan zeolit terjadi ketika campran dalam otoklaf mengalami kenaikan suhu, ketika suhu mulai meningkat lebih dari $100^{\circ} \mathrm{C}$ air akan mendidih dan terjadi proses dealuminasi dan pemutusan rantai $\mathrm{SiO}$ pada kerangka zeolit mordenit oleh ion $\mathrm{OH}$ - dari $\mathrm{NaOH}$, ini merupakan proses tahap pertama (proses kondensasi polisilikat dan anion aluminat). Kemudian tahap berikutnya adalah proses nukleasi zeolit, pada proses ini setelah kerangka zeolit mordenit terurai menjadi unit bangunan sekunder maka dibentuk kembali rangkaian zeolit jenis baru yaitu pada percobaaan ini terbentuk zeolit faujasit. proses nukleasi dipengaruhi oleh kation-kation dan agen pengarah struktur, dimana logam-logam oksida dalam geometri sangat disukai karena gaya elektrostatisnya dan interaksi Van Der Waals [7]. Air zamzam yang digunakan sebagai sumber akuades memiliki ion-ion logam terlarut yang bertindak sebagai templat anorganik atau agen pengarah struktur dimana lubang-lubang kosong (pori-pori) pada kerangka zeolit akan di isi oleh logam-logam yang terdapat dalam air zamzam. Setelah proses nukleasi kemudian terjadi pertumbuhan kristal, proses petumbuhan kristal disini merupakan suatu proses dimana atom atau molekul bergabung ke dalam permukaan kristal 
yang menyebabkan peningkatan ukuran sehingga terbentuknya kristal zeolit yang kompleks.

Secara termodinamika terbentuknya zeolit faujasit dari transformasi zeolit mordenit ini jarang terjadi dikarenakan perubahan dari kerapatan yang tinggi kepada kerapatan yang rendah, zeolit faujasit memiliki kerapatan $12,7 \mathrm{~T} /$ $1000 \AA^{3}$ dan zeolit mordenit memiliki kerapatan sebesar 17,2 T/ $1000 \AA^{3}$. Sedangkan yang sering terjadi pada transformasi atau sintesis zeolit perubahan dari kerapatan yang rendah kepada kerapatan yang tinggi atau dengan kata lain dapat dikatakan pembentukan zeolit mordenit dari dari zeolit faujasit akan mudah terbentuk daripada sebaliknya. Selain itu terbentuknya zeolit faujasit dapat dilihat dari segi pembentuk unit bangunan sekunder dari zeolit faujasit dan terbentuknya zeolit faujasit dikarenakan adanya unit bangunan sekunder zeolit faujasit pada kerangka jenis zeolit mordenit, dapat dilihat pada Gambar 2 zeolit faujasit di bentuk oleh unit bangunan sekuder 4 dan 6 yang ada pada kerangka zeolit mordenit. Zeolit faujasit memiliki pori besar seperti MOR dan BEA, yaitu bukaan pori zeolit dibentuk oleh $12 \mathrm{TO}_{4}$ tetrahedra dengan diameter sekitar 7,5 ̊. Zeolit faujasit memiliki kerangka mirip seperti zeolit LTA dan sodalit yang terdiri atas 24 atom T (enam cincin-4 atau empat cincin-6). Faujasit berasal dari kerangka SOD yang dihubungkan melalui cincin-6 ganda ke dalam lapisan faujasit [6]. Periodik unit bangunan dua dimensi diperoleh ketika kerangka SOD dihubungkan melalui 6cincin ganda (D6Rs) ke dalam lapisan faujasit heksagonal.
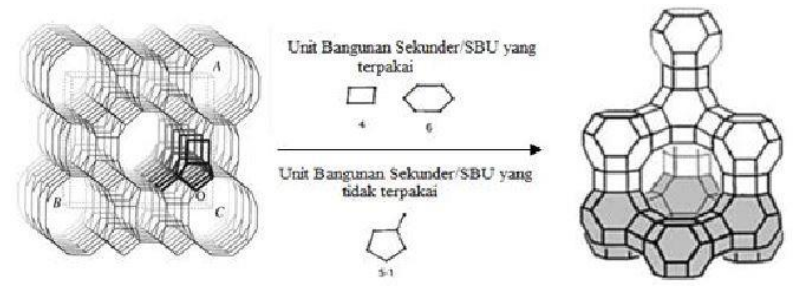

Gambar 2. Ilustrasi pembentukan zeolit faujasit dari zeolit mordenit.

Mineral kuarsa terbentuk kembali karena pada komposisi campuran prekursor terlalu basa. Hal ini terjadi ketika $\mathrm{NaOH}$ berlebih, ion dari $\mathrm{OH}-$ memotong rangkaian Si nya hingga molekul kecil sehingga terbentuk kembali $\mathrm{SiO}_{2}$ dan $\mathrm{H}_{2} \mathrm{O}$.

\section{Transformasi Percobaan B}

Perbandingan mol pada percobaan ini adalah 1:2:40 komposisi zeolit dan air zamzam sama dengan mol dari percobaan $\mathrm{A}$, namun $\mathrm{NaOH}$ yang digunakan setengahnya. Dari transformasi pada perbandingan mol ini berdasarkan karakterisasi difraksi sinar-X menghasilkan zeolit faujasit dan zeolit analsim. Pada percobaan A menghasilkan zeolit faujasit dan mineral kuarsa sedangkan pada percobaan B menghasilkan zeolit faujasit dan zeolit analsim. Hal tersebut menunjukan bahwa pengaruh $\mathrm{NaOH}$ pada transformasi sangat kuat, ketika $\mathrm{NaOH}$ yang di tambahkan pada prekursor dalam jumlah banyak maka terbentuk mineral kuarsa dikarenakan rantai $\mathrm{SiO}$ terpotong hingga molekul terkecil. Terbentuknya zeolit faujasit ini dikarenakan adanya unit bangunan sekunder zeolit faujasit pada kerangka jenis zeolit mordenit. Pembentukan zeolit faujasit dapat dilihat pada Gambar 2. yang di bentuk oleh unit bangunan sekuder 4 dan 6 yang ada pada kerangka zeolit mordenit seperti yang di jelaskan pada percobaan A. Proses pembentukan kristal zeolit analsim juga sama seperti pembentukan zeolit faujasit melalui tahaptahap yang sama.

Secara termodinamika pembentukan zeolit analsim dari transformasi zeolit mordenit mudah terbentuk dikarenakan zeolit mordenit memiliki kerapatan sebesar 17,2 T/ $1000 \AA^{3}$ dan zeolit analsim memiliki kerapatan $18,5 \mathrm{~T} / 1000 \AA^{3}$, proses yang terjadi dari kerapatan yang rendah kepada kerapatan yang tinggi. Selain itu, terbentuknya zeolit analsim dari transformasi ini dikarenakan kerangka unit bangunan sekunder dari zeolit analsim terdapat pada kerangka zeolit mordenit, dapat dilihat pada Gambar 3 zeolit analsim dibentuk oleh unit bangunan sekunder cincin-4 dan cincin-6 yang terdapat pada kerangka mordenit.

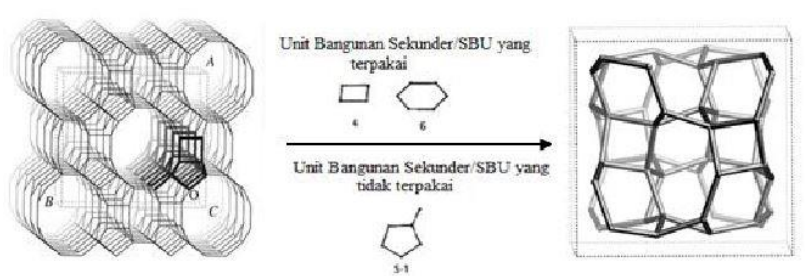

Gambar 3. Ilustrasi pembentukan zeolit analsim dari zeolit mordenit.

Dilihat dari analisis difraksi sinar-X hasil transformasi masih terdapat puncak-puncak mineral pengotor, hal ini terjadi disebabkan penggunaan suhu yang kurang tinggi. Dalam penelitian yang dilakukan oleh Juniantoro dkk pada sintesis zeolit analsim dari kaolin dengan variasi waktu dan suhu telah ditemukan makin tinggi suhu dan makin lama waktunya, maka zeolit analsim yang di hasilkan makin murni [8]. Maka dari itu untuk menghasilkan produk zeolit analsim yang lebih murni, suhu yang digunakan harus ditingkatkan. 


\section{Transformasi Percobaan C}

Transformsi pada variasi perbandingan mol ini tidak terjadi perubahan yang signifikan, hasil pengujian difraksi sinar- $X$ dari transformasi ini komposisinya hampir sama dengan sampel awal yaitu zeolit mordenit dan mineral kuarsa, sedangkan komposisi pada sampel awal terdeteksi zeolit mordenit, mineral kuarsa, dan zeolit klinopltilolit. Pada transformasi ini tidak terbentuk zeolit baru dikarenakan tidak menggunakan $\mathrm{NaOH}$ pada komposisi pekursornya. Namun ada komposisi yang hilang pada hasil transformasi ini yaitu zeolit klinoptilolit, hilangnya zeolit klinoptilolit dipengaruhi oleh air zamzam yang digunakan sebagai sumber akuades.

Pada transformasi ini tidak digunakan $\mathrm{NaOH}$ sebagai prekursor bertujuan untuk mengetahui pengaruh dari air zamzam pada transformasi, dikarenakan air zamzam memiliki $\mathrm{pH}$ basa dan ion $\mathrm{F}^{-}$dimana ion $\mathrm{F}^{-}$ini memiliki peran yang sama dengan ion $\mathrm{OH}^{-}$yang berperan sebagai mineraliser (pemutus rantai $\mathrm{Si}$ ) yang dapat membentuk kerangka zeolit baru. Namun kebasaan dari air zamzam tidak terlalu kuat dan kadar $\mathrm{F}^{-}$sangat kecil karena ion $\mathrm{F}^{-}$ini hanya ion terlarut saja dalam air zamzam, sehingga pengaruh dari ion $\mathrm{F}^{-}$ini tidak terlalu kuat untuk memutus rantai Si dalam jumlah besar, artinya yang terpotong hanya sedikit saja.

\section{Karakterisasi Zeolit hasil Transformasi dengan Difraksi Sinar-X}

Zeolit hasil transformasi dikarakterisasi dengan menggunakan difraksi sinar-X untuk mengetahui kristalinitasnya. Dari ketiga variasi perbandingan mol yang dikarakterisasi didapatkan data analisis sebagai berikut:

\section{Karakterisasi hasil Transformasi Percobaan A}

Hasil analisis difraksi sinar-X zeolit transformasi pada percobaan ini terbentuk dua mineral yaitu faujasit dan kuarsa. Pada struktur zeolit faujasit standar akan memberikan puncak yang khas pada $2 \theta=6^{\circ} ; 10^{\circ} ; 12^{\circ} ; 15,5^{\circ} ; 18,5^{\circ}$; $20^{\circ} ; 23,5^{\circ} ; 27^{\circ} ; 30,5^{\circ} ; 31,5^{\circ} ; 32,2^{\circ} ; 33^{\circ} ; 33,5^{\circ}$; $34^{\circ} ; 36^{\circ}$ dan $36,7^{\circ}$. Sedangkan pada struktur mineral kuarsa standar akan memberikan puncak yang khas pada $2 \theta=20,94^{\circ} ; 26,69^{\circ} ; 36,68^{\circ}$; $39,5^{\circ}$ : $40,3^{\circ} ; 42,53^{\circ}$; dan $45,86^{\circ}$. Diftraktogram zeolit hasil transformasi pada variasi pada perbandingan rasio berat 1 Zeolit : $2 \mathrm{NaOH}: 2$ Akuades : 40 Air zamzam dapat dilihat pada Gambar 4.

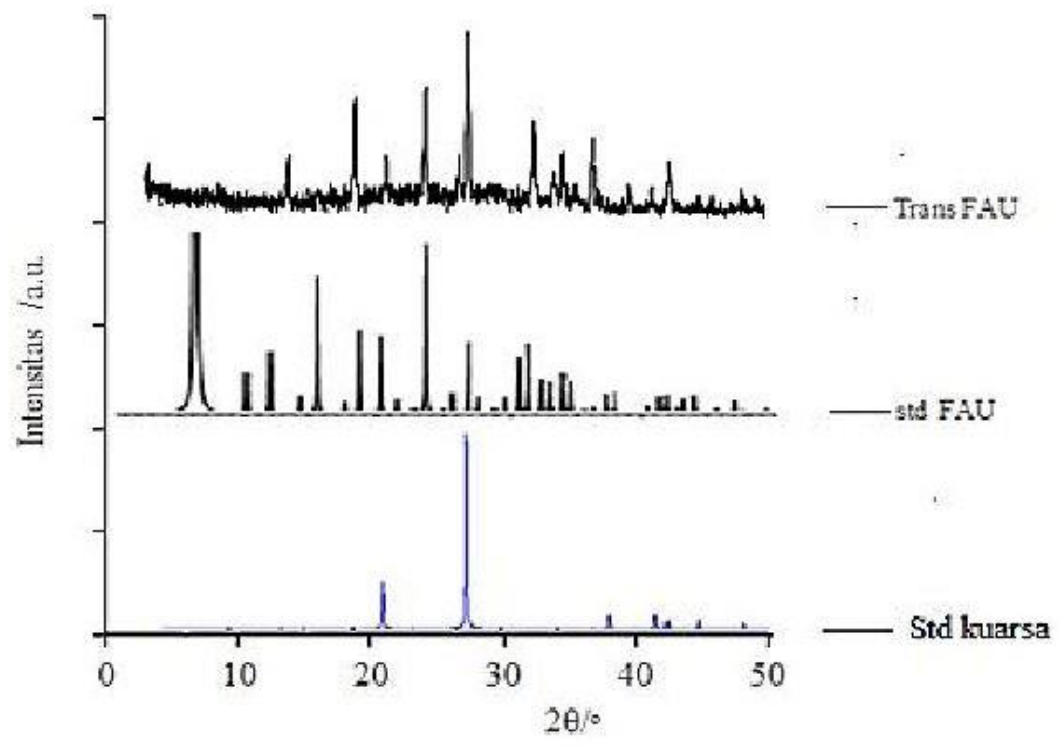

Gambar 4. Difraktogram Hasil Transformasi (Trans FAU), standar Faujasit (std FAU), standar Kuarsa (Std kuarsa)

Berdasarkan hasil analisis tersebut dapat dilihat bahwa puncak-puncak difraktogram hasil transformasi dapat memberikan puncak yang khas sesuai dengan puncak khas dari zeolit standar faujasit dan standar mineral kuarsa. Hal tersebut mengindikasikan bahwa hasil zeolit yang ditransformasi pada variasi perbandingan mol ini merupakan zeolit faujasit dan mineral kuarsa.

\section{Karakterisasi hasil Transformasi Percobaan B}

Hasil analisis difraksi sinar-X zeolit transformasi pada percobaan ini terbentuk dua mineral yaitu faujasit dan analsim. Pada struktur zeolit faujasit standar akan memberikan puncak yang khas pada $2 \theta=6^{\circ} ; 10^{\circ} ; 12^{\circ} ; 15,5^{\circ} ; 18,5^{\circ}$; $20^{\circ} ; 23,5^{\circ} ; 27^{\circ} ; 30,5^{\circ} ; 31,5^{\circ} ; 32,2^{\circ} ; 33^{\circ} ; 33,5^{\circ}$; 
$34^{\circ} ; 36^{\circ}$ dan $36,7^{\circ}$. Sedangkan pada struktur zeolit analsim standar akan memberikan puncak yang khas pada $2 \theta=15,82^{\circ} ; 18,26^{\circ} ; 25,12^{\circ} ; 30,52^{\circ}$ : $33,26^{\circ} ; 35,78^{\circ} ; \quad 37^{\circ} ; \quad 40,48^{\circ}$ dan $48,68^{\circ}$.
Diftraktogram zeolit hasil transformasi pada variasi pada perbandingan rasio berat 1 Zeolit : 1 $\mathrm{NaOH}: 1$ Akuades : 40 Air zamzam dapat dilihat pada Gambar 5.

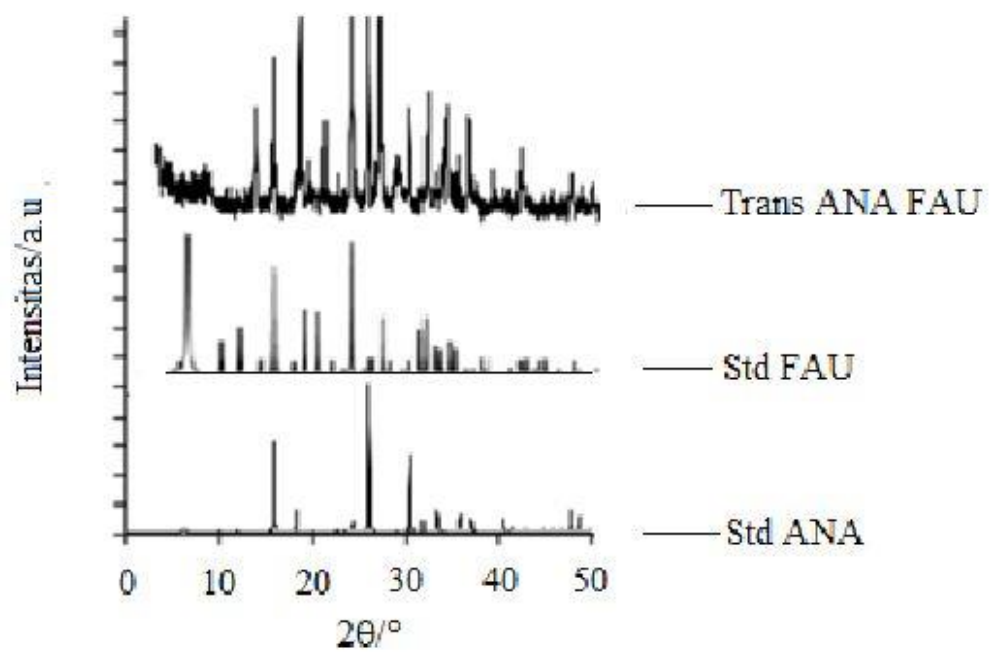

Gambar 5. Difraktogram Hasil Transformasi (Trans ANA FAU), standar Faujasit (Std FAU), standar Analsim (Std ANA)

Berdasarkan hasil analisis tersebut dapat dilihat bahwa puncak-puncak difraktogram hasil transformasi dapat memberikan puncak yang khas sesuai dengan puncak khas dari zeolit standar faujasit dan standar zeolit analsim. Hal tersebut mengindikasikan bahwa hasil zeolit yang ditransformasi pada variasi perbandingan mol ini merupakan zeolit faujasit dan analsim. Dilihat dari perbandingan difraktogram masih banyak terdapat puncak-puncak pengotor pada zeolit hasil transformasi.

\section{Karakterisasi hasil Transformasi Percobaan C}

Hasil analisis difraksi sinar-X zeolit transformasi pada percobaan ini terbentuk dua mineral yaitu mordenit dan kuarsa. Pada struktur zeolit mordenit standar akan memberikan puncak yang khas pada $2 \theta=6,48^{\circ} ; 8,6^{\circ} ; 9,76^{\circ} ; 13,84^{\circ}$; $14,58^{\circ} ; 19,58^{\circ} ; 22,18^{\circ} ; 23,16^{\circ} ; 25,62^{\circ} ; 26,2^{\circ}$; $27,64^{\circ} ; 30,86^{\circ}$; dan $35,58^{\circ}$. Sedangkan pada struktur mineral kuarsa standar akan memberikan puncak yang khas pada $2 \theta=20,94^{\circ} ; 26,69^{\circ}$; $36,68^{\circ}$; $39,5^{\circ}$ : $40,3^{\circ} ; 42,53^{\circ}$; dan $45,86^{\circ}$. Diftraktogram zeolit hasil transformasi pada variasi pada perbandingan rasio berat 1 Zeolit : 0 $\mathrm{NaOH}: 0$ Akuades : 40 Air zamzam dapat dilihat pada Gambar 6.

Berdasarkan hasil analisis tersebut dapat dilihat bahwa puncak-puncak difraktogram hasil transformasi dapat memberikan puncak yang khas sesuai dengan puncak khas dari zeolit standar mordenit dan standar mineral kuarsa. Hal tersebut mengindikasikan bahwa hasil zeolit yang ditransformasi pada variasi perbandingan mol ini merupakan zeolit mordenit dan mineral kuarsa. Pada percobaan ini tidak terjadi perubahan yang signifikan, difraktogram hasil transformasi tidak jauh berbeda dengan sampel awal (zeolit alam) yang digunakan.

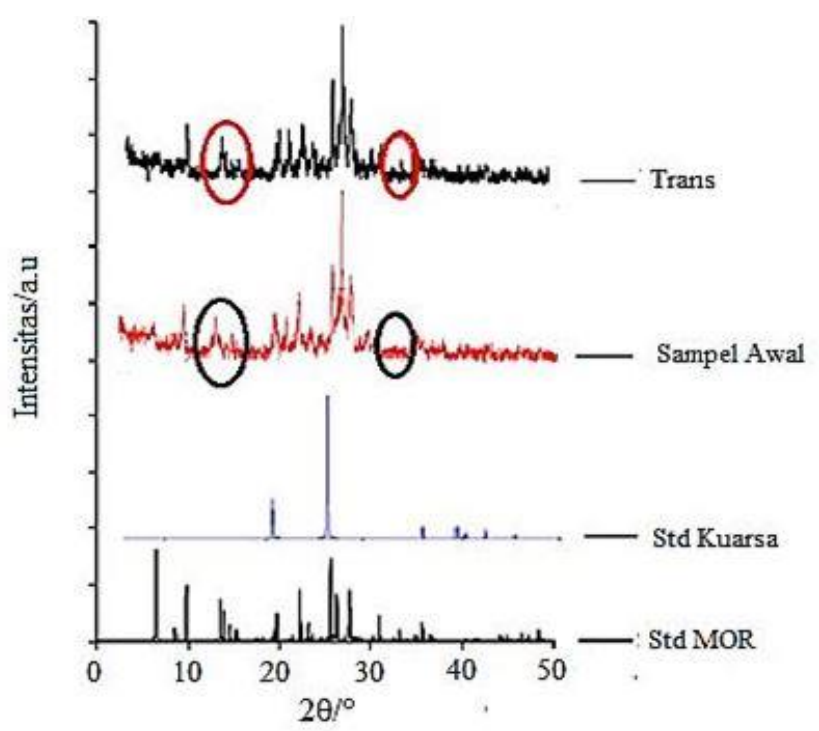

Gambar 6. Difraktogram Hasil Transformasi (Trans), sampel awal, standar kuarsa (Std Kuarsa), standar Mordenit (Std MOR)

\section{SIMPULAN}

Dari hasil penelitian ini dapat ditarik kesimpulan sebagai berikut: 
1. Zeolit alam asal sukabumi dapat ditransformasi menjadi zeolit baru yaitu pada percobaan A terbentuk zeolit faujasit dan mineral kuarsa, pada percobaan B terbentuk zeolit faujasit dan analsim. Pada percobaan $\mathrm{C}$ tidak terbentuk zeolit baru, namun kandungan zeolit klinoptilolit menghilang dan terdapat puncak-puncak baru yang muncul pada difraktogtam yang dipengaruhi oleh air zamzam.

2. Karakteristik berdasarkan pengujian difraksi sinar-X menunjukan pada zeolit hasil transformasi memiliki puncak-puncak yang identik dengan puncak-puncak zeolit standar.

\section{UCAPAN TERIMA KASIH}

Penulis mengucapkan terima kasih kepada seluruh pihak yang telah membanntu dalam menyelesaikan penelitian ini, Terima kasih kepada Jurusan Kimia, dan Laboratorium Kimia Terpadu atas bantuannya dalam memberikan fasilatas peminjaman laboratorium, alat serta support bahan-bahan pada penelitian ini.

\section{REFERENSI}

[1] A. M. d. U. Basri, Bahan Galian Industri Zeolit, Bandung: Pusat Penelitian dan Pengembangan Teknologi Mineral, 1995.

[2] A. M. d. Harsodo, Zeolit alam, potensi, teknologi, kegunaan dan prospeknya du Indonesia, Bandung: Pusat Penelitian dan Pengembangan Teknologi Mineral, 1991.
[3] I. Budi, Penanaman Ti Pada Struktur Tetrahedral Zeolit Alam:sebagai Persiapan Bahan Foto Katalisis Limbah Zat Warna NonBiodegredeble, Bandung: Universitas Islam Negeri Sunan Gunung Djati Bandung, 2013.

[4] G. I. e. al, Transformastion of LEV-type zeolite into less dense CHA-type zeolite, Japan: Hiroshima University HagashiHiroshima Elsevier, 2012.

[5] S. M. Auerbach, K. A. Carrado dan P. K. Dutta, Zeolite Science and Tecnology, New York: Marcel Dekker, Inc, 2003.

[6] R. Xu, W. Pang, J. Yu, Q. Huo dan J. Chen, "Chemistry of Zeolites and Related Porous Material: Syntesis and Structure," dalam 2007, Singapura, pp. p. $23-25$, p. $50-52$, p. 122 , p. 124, p. 175.

[7] P. Cubillas dan M. W. Anderson, "Crystal Growth and Nucleation," in in Zeolite and Catalysis, Reactions and Aplications," dalam Synthesis Mecanism, Weinhem, 2010, pp. pp. $1-55$.

[8] H. D. d. P. D. Juniantoro Frans Eko, Sintesis Analsim dari Kaolin secara Langsung: Pengaruh Suhu dan Waktu Kristalisasi, Jurusan Kimia, Fakultas Matematika dan Ilmu Pengetahuan Alam,Institut Teknologi Sepuluh Nopember (ITS), 2014. 